\title{
Transfigurasi Hukum Islam dalam Sistem Hukum Nasional
}

\section{Yusdani}

Transfiguration of Islamic law into Indonesian legal system is seen as a way to the legalization of figh into modem legal system. To make this transfiguration run smoothly, the process should be built on the full recognition of political and scientific dynamics in society. Thus, far from the classical theory of receptie during early colonialization era, this transfiguration must be made in the corridor of democracy and academic maturity.

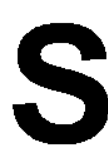
etelah runtuhnya rezim Orde Baru dan memasuki periode reformasi, In donesia memasuki era demokratisasi meskipun kini masih dalam transisi dan dalam batas retorika. Dalam kondisi Indonesia seperti íni keterlibatan masyarakat dalam pengambilan keputusan untuk urusan publik terbuka lebar, di samping itu masyarakat juga mempunyai kebebasan dalam mengadopsi nilai-nilai untuk kehidupan masa depannya. Termasuk dalam konteks ini kompetisi bebas dalam percaturan nilai yang kemudian menjadi tatanan masyarakat atau sumber hukum. ${ }^{1}$

Dalam kehidupan masyarakat di atas, nilai global akan lebih mempunyai keleluasaan untuk masuk ke dalam sistem sosial Indonesia. Dalam waktu bersamaan, nilai-nilai agama termasuk hukum agama juga mempunyai kesempatan lebih luas dibandingkan dengan pada masa sebelum era reformasi. Oleh karena itu, pola dan model pemaksaan dalam pemberlakuan hukum Islam tampaknya tidak sesuai dengan semangat reformasi. ${ }^{2}$

Dalam pembinaan dan pembangunan di Indonesia tiga elemen sumber hukum yaitu hukum kebiasaan, hukum Barat dan hukum Islam mempunyai kedudukan sama dan seimbang. Namun pengembangan tiga sumber hukum tersebut tetap dituntut agar mencerminkan kompetisi bebas dan kemungkinan terjadinya eklektisisme, bukan dengan cara pemaksaan dari rezim yang berkuasa untuk menerapkan salah satu sumber tersebut. Dalam konteks ini, usaha dengan cara demokratisasi juga mempunyai kesempatan dan fungsi yang sangat menentukan, oleh karena itu kepentingan umum hendaklah menjadi acuan dalam pengambilan keputusan untuk publik, termasuk hukum. Ketika kompetisi yang demokratis itu terjadi, usaha secara konseptual menjadi bagian strategis yang tidak dapat diabaikan. Sehingga ketika pembicaraan mengenai hukum Islam sebagai salah satu sumber hukum nasional, diperlukan sistem kerja transfigurasi hukum Islam yang dapat diterima secara keilmuan dan dalam proses demokratisasi. ${ }^{3}$

A. Qodri Azizy.2002. Eklektisisme Hukum Nasional Kompetisi Antara Hukum Islam dan Hukum Umum (Yogyakarta:Gama Media), him. 171.
2 Ibid. him.172-173.
3 lbid. hlm. 173. 


\section{Kebijakan Pembangunan Hukum Nasional}

Sebagai konsekuensi perubahan politik memasukiera reformasi, arah dan kebijakan hukum nasional yang juga sekaligus merupakan perubahan politik hukum nasional berlandaskan pada Garis-Garis Besar Haluan Negara(GBHN) tahun 1999, merupakan produk era reformasi. Dengan kata lain, berbicara mengenai arah kebijakan hukum nasional, haruslah dilandasi dengan kehendak rakyat Indonesia dalam era reformasi yang tertuang dalam GBHN 1999. Arah Kebijakan GBHN dalam pembangunan dan pembinaan hukum di Indonesia disebutkan, antara lain:Menata sistem hukum nasional yang menyeluruh dan terpadu dengan mengakui dan menghormati hukuim agama dan hukum adat serta memperberbaharui perundang-undangan warisan kolonial dan hukum nasional yang diskriminatif, termasuk ketidakadilan gender dan ketidaksesuaiannya dengan tuntutan reformasi melalui program legislasi. ${ }^{4}$

- Dari ungkapan tersebut dapat dipahami bahwa pembangunan hukum nasional secara garis besar bersumber pada hukum adat, hukum Islam, dan hukum Barat. Sekalipun pembahasan tentang ketiga sumber tersebut sebenarnya sudah pernah dilakukan pada era Orde Baru, namun tetap saja tidak secara tegas hukum Islam diberi tempat dalam sistem hukum nasional. Kalau mau jujur, di negara manapun termasuk Barat, hukum yang dipakai pada dasarnya berasal dari berbagai sumber. HAM (hak asasi manusia) di Barat sebenarnya juga tidak lepas dari pengaruh hukum Isiam dalam tataran pemikiran awalnya. Hukum Barat dalam kajiannya di Indonesia sekarang ini hendaklah dipahami sebagai hukum yang sudah ada yang merupakan warisan kolonial dan hukum masa depan merupakan perwujudan eklektisisme dalam ilmu hukum dan pengaruh globalisasi. Tidak mungkin sebuah negara dapat lepas sama sekali dari pengaruh dunia luar, terlebih lagi dunia Barat. Hukum Adat, hendaknya dipahami sebagai hukum yang hidup dalam masyarakat. Jika hukum adat dipahami sebagai living law atau customary law-termasuk dengan nama common law- hal ini pun terjadi di Barat yang sering dianggap sebagai negara modern. ${ }^{5}$

Kerangka atau paradigma seperti halnya terjadi di semua negara di dunia, khususnya negara yang menghargai hak asasi manusia dan keterbukaan, termasuk keterbukaan sumber hukum positifnya. Dengan kata lain, pada era reformasi sekarang ini akan terbuka lebar terjadinya kompetisi saling mempengaruhi budaya masyarakat dan dalam waktu bersamaan ada kesempatan pula bagi masyarakat untuk menentukan pilihan-pilihannya sebagai perwujudan HAMtermasuk untuk menentukan jenis atau model hukum yang akan dipakai. Tentu hal demikian ini dapat dibicarakan dalam konteks, model, jalan, atau alur nilai sampai dengan etika dalam pelbagai bentuk untuk dapat menjalankan hukum tersebut, baik melalui peraturan perundang-undangan, putusan hakim, kebiasaan dan doktrin maupun kultural dalam bentuk customary law dan arbitrasi. ${ }^{6}$

Pembahasan posisi hukum Islam di tengah-tengah hukum nasional, kini sudah tidak zamannya lagi mencari legitimasi keberadaan hukum Islam. Era pertarungan antara teori resepsi dengan hukum Islam atau dengan teori receptio in complexu ${ }^{7}$ sudah selesai. Oleh karena itu, pembahasan

\footnotetext{
${ }^{4}$ GBHN 1999 Bab IV. A. 2

${ }^{5}$ A. Qodri Azizy, Eklektisisme...hlm. 176.

${ }^{6}$ Ibid.
} 
posisi hukum Islam tidak sekadar mencari legitimasi legal formal, namun harus diarahkan pada seberapa banyak hukum Islam mampu menyumbangkan nilai-nilainya dalam rangka kemajuan, keteraturan, ketenteraman dan kesejahteraan dalam kehidupan berbangsa dan bernegara. ${ }^{8}$

Dalam ungkapan GBHN yang dikutip di atas, dengan tegas adanya program legislasi nasional yang isinya terutama sekali berupa materi perundang-undangan. Memang, meskipuin Indonesia tidak mengikuti sistem Roman law atau civil law, seperti negeri Belanda, yang sangat ketat keterikatan hakim terhadap undang-undang, namun undang-ündang merupakan acuan utama. Undang-Undang dalam tertib sumber hukum di Indonesia merupakan urutan ketiga setelah UUD dan TAP MPR, sebagaimana dalam TAP MPR No. III/MPR/2000. Untuk membuat sebuah undang-undang, menurut GBHN 1999 ada tiga bahan baku, yang salah satunya adalah hukum Islam, sebagaimana ungkapan di atas. Ketika berbicara mengenai transfigurasi hukum Islam, sasaran utamanya adalah menjadikan hukum Islam sebagai sumber pembuatan undang-undang. Tentu, meliputi juga dalam pengertian lain yang lebih luas, termasuk putusan hakim, kebiasaan, dan doktrin. Program legislasi sangat besar dan penting, oleh karena akan mencakup perubahan undang-undang warisan Belanda dan undang-undang lama yang dianggap sudah tidak sesuai dengan perkembangan masyarakat. Perlu diingat bahwa masyarakat berkembang sangat cepat dan pesat. Terutama sekali dengan adanya globalisasi seperti sekarang ini. Sementara itu, hukum sangat statis, sehingga perlu ada perubahan yang sistematis, di samping perlu adanya keberanian pemaknaan atau interpretasi hukum oleh hakim agar tidak ketinggalan dan akan memenuhi rasa keadilan masyarakat. Dengan demikian, perlu ada revisi serius terhadap anggapan umum yang berlaku di masyarakat hukum, termasuk di dunia perguruan tinggi. Anggapan umum itu yang selama ini ada adalah apa yang ditulis dalam buku-buku yang menjadi bahan utama pelajaran di perguruan tinggi tentang hukum Indonesia, seperti contoh, sebagai berikut:' Dengan versi yang lebih khas hukum di Indonesdia tumbuh dari kebiasaan dalam masyarakat yang dikenal sebagai hukum adat. $^{9}$

\section{Sistem Hukum Nasional Era Reformasi}

Sistem hukum Indonesia menganut apa yang disebut dengan Rechtsvinding ${ }^{10}$ plus atau legal realism ${ }^{11}$ plus. Ungkapan plus tersebut adalah penjelasan pertanggungjawaban setiap hakim kepada Tuhan Yang Maha Esa. Hal ini berdasarkan argumentasi ungkapan dalam pasal 27 (1) dan pasal 14 (1) dengan penjelasannya $U U$ No. 14 tahun 1970 tersebut diatas hendaknya juga memberi arti setiap hakim berhak menilai apakah suatu pasal dalam undang-undang itu masih sesuai atau tidak dengan sesuai dengan perkembangan zaman sehingga harus ditinggalkan atau perlu ada penafsiran yang lebih tepat. Jika bunyi undang-undang itu dianggap sebagai

${ }^{7}$ Sajuti Thalib.1982. Receptio A Contrario (Hubungan HukumAdat dengan Hukum Islam). Jakarta: Bina Aksara.

${ }^{8}$ A.Qodri Azizy. Eklektisisme. hlm. 176-177

${ }^{9}$ Ibid. hlm.177-178.

${ }^{10}$ C.S.T. Kansil dan Christine S.T. Kansil. 2000. Pengantar llmu Hukum dan Tata Hukum Indonesia ( Jakarta: Balai Pustaka), hlm. 158-160.

11 Jeffrie Murphy dan Jules.1984. The Philosophy of Law ( New Jersey: Rowman \& Allanheld), hlm.22-42. 
sebuah teks, pemahamannya tidak harus tekstual, namun dalam banyak hal justru kontekstual. Akan tetapi, syarat utamanya adalah bahwa moralitas dan integritas hakim harus terjamin. Pemahaman seperti ini didukung oleh adanya kedudukan dan peran kekuasaan kehakiman yang dengan tegas disebutkan bahwa Peradilan Negara menetapkan dan menegakkan hukum dan keadilan yang berdasarkan Pancasila ( pasal 2 ayat [2] UU No. 14 tahun 1970). Dalam UU No. 14 tahun 1970 tidak pernah disebutkan bahwa hakim harus terikat atau tunduk kepada undang-undang. Akan tetapi, penjelasan ini tetap berbeda dengan aliran Freie Rechts bewegung, karena aliran ini menganggap bebas sama sekali bagi hakim kaitannya dengan undang-undang dan tidak adanya tanggung jawab kepada Tuhan yang mempunyai konsekuensi ganda di dunia dan di akhirat kelak. Hakim seperti Bismar Siregar, merupakan contoh pelaksana paham Rechtsvinding-plu' ${ }^{12}$ tersebut.

Namun harus pula diingat bahwa keberadaan undang-undang di Indonesia tetap dibutuhkan sebagai wujud hukum positif yang formal dalam rangka unifikasi dan kepastian hukum serta mempermudah untuk penegakan hukum. Di samping itu, kondisi penegak hukum, terutama sekali hakim, seperti sekarang ini sangat memerlukan undang-undang yang rinci dan lengkap untuk semua aspek kehidupan masyarakat dan bangsa Indonesia, meskipun harus dipahami secara kontekstual. Yang perlu diingat adalah bahwa penyusunan undang-undang itu harus bersumber pada tiga macam bahan baku hukum nasional sebagaiaman ditegaskan di dalam GBHN 1999 di atas. Dengan kata lain, dapat dikatakan bahwa sistem hukum nasional mengikuti paham sejalan dengan aliran legal realism, seperti yang berjalan di Amerika Serikat dan lebih dari itu, oleh karena adanya pertanggungjawaban kepada Tuhan Yang maha Esa secara langsung, sehingga disebut plus di atas. ${ }^{13}$

\section{Hukum dan Keadilan}

Sebagai konsekuensi sistem hukum di indonesia menganut paham legal realismplus atau Rechtsvinding - plus, adalah adanya keharusan setiap hakim untuk mengedepankan terwujudnya rasa keadilan masyarakat. Sebagai pemberi putusan yang pertanggung-jawaban utamanya kepada Tuhan YME, kemudian juga kepada bangsa dan negara, hakim di samping harus berhatihati juga hendaknya mengedepankan dan berorientasi pada kepentingan umat, bukan untuk kepentingan perorangan. Keadilan seperti inilah yang dituntut oleh sistem hukum Indonesia. Tuntutan keadilan masyarakat dapat dibaca di dalam penjelasan dan úraian sebagai berikut:

Dalam masyarakat yang masih mengenal hukum tidak tertulis, serta berada dalam masa pergolakan dan peralihan, Hakim merupakan perumus dan penggali dari nilai-nilai hukum yang hidup di kalangan rakyat. Untuk itu ia harus terjun ke tengahtengah masyarakat untuk mengenal, merasakan dan mampu menyelami perasaan hukum dan rasa keadilan yàng hidup dalam masyarakat. Dengan demikian, Hakim dapat memberikan putusan yang sesuai dengan hukum dan rasa keadilan masyarakat. ${ }^{14}$

Dalam rangka meletakkan hukum dan hakim pada posisi yang sesuai dengan paham yang dianut oleh sistem hukum nasional dan bertitik-tolak dari TAP MPR No.

\footnotetext{
${ }^{12}$ A. Qodri Azizy, Eklektisisme....h.hm.215

${ }^{13}$ Ibid. hlm.215-216.

14 Undang-Undang No. 14 tahun 1970
} pasal 27 ayat (1). 
X/MPR/1998 sebagai hasil Sidang Istimewa MPR tanggal 13 November 1998, upaya memisahkan lembaga yudikatif dari cengkeraman lembaga eksekutif mulai digulirkan. Upaya tersebut berupa pembentukan Tim Kerja Terpadu Pengkajian Pelaksanaan TAP MPR No. X/MPR/1998 berkaitan dengan pemisahan yang tegas fungsi yudikatif dari eksekutif. Pembentukan Tim ini berdasarkan Keputusan presiden RI No. 21 tahun 1999 tanggal 17 Maret 1999 jo. Keputusan presiden RI No. 42 tahun 1999 tanggal 18 Mei 1999. Tim ini bekerja sangat cepat sehingga bermula dari rekomendasi Tim ini, lahirlah Undang-Undang Nomor 35 tahun 1999 tentang perubahan atas UndangUndang Nomor 14 tahun 1970 tentang ketentuan-ketentuan Pokok Kekuasaan Kehakiman. Pemisahan kekuasaan yudikatif dari kekuasaan eksekutif, yang terpenting dalam perubahan ini adalah pasal 11. Pasal 11 UU No. 14 tahun 1970 berbunyi sebagai berikut:

Badan-badan yang melakukan peradilan tersebut pasal 10 ayat (1) organisatoris, administratif dan finansial ada di bawah kekuasaan masing-masing Departemen. yang bersangkutan;

Dalam UU No. 35 tahun 1999, pasal 11 di atas berubah secara mendasar, sehingga berbunyi sebagai berikut:

(1) Badan-badan peradilan sebagaimana dimaksud dalam pasal 10 ayat (1), secara organisatoris, administratif dan finansial ada di bawah kekuasaan Mahkamah Agung;

(2) Ketentuan mengenai organisasi, administrasi dan finansial sebagaimana dimaksud dalam ayat (1) untuk masingmasing lingkungan peradilan diatur lebih lanjut dengan undang-undang sesuai dengan kekhususan lingkungan peradilan masing-masing. ${ }^{15}$
Kemudian di antara pasal 11 dan pasal 12 disisipkan pasal baru berupa pasal 11A, yang isinya berupa waktu penyerahan kekuasaan organisatoris, administratif dan finansial dari departemen, yang berati kekuasaan eksekutif, ke Mahkamah Agung, yang berarti kekuasaan yudikatif. Lepasnya lembaga peradilan dari cengkeraman kekuasaan eksekutif lewat organisasi, administrasi dan finansial di atas dimaksudkan untuk menjadikan hakim benar-benar mandiri, tidak terpengaruh oleh kekuasaan eksekutif. Dengan demikian, diharapkan kerja hakim sungguh-sungguh mampu menegakkan hukum, tanpa ada kendala intervensi kekuasaan eksekutif, dan mampu pula mewujudkan rasa keadilan masyarakat. Dengan kata lain, semestinya UU No. 35 tahun 1999 mampu memberi jalan kepada hakim untuk menjalankan tugasnya sebagai hakim yang mempunyai tanggung jawab kepada Tuhan YME dalam sistem Hukum nsional yang menganut paham Rechtsvinding-plus. Akan tetapi tampaknya, ungkapan yang selalu muncul dalam setiap keputusan resmi Pengadilan di Indonesia belum menjadi wacana publik untuk dibahas secara mendalam dari filosofis, etis dan implikasi sosial, terutama sekali dalam aspek keagamaan. ${ }^{16}$

Ungkapan "nilai-nilai yang hidup di masyarakat" mempunyai arti luas. Hal demikian ini dapat mencakup adat kebiasaan (customary law/iving law), selalu berarti hukum adat seperti dalam definisi yang ada, dan akan selalu terjadi perkembangan. Dalam waktu bersamaan, juga dapat mencakup hukum Islam, karena Islam dengan perangkat hukumnya pedoman para pemeluknya. Hal ini juga

15 Undang-Undang No. 35 tahun 1999

${ }^{16}$ A. Qodri Azizy. Eklektisisme...hlm.225. 
sekaligus memberi kesempatan hakim dalam dunia praktisi di lembaga peradilan untuk mempertimbangkan atau bahkan menggunakan hukum Islam. ${ }^{17}$

\section{Hukum Islam, Etika Hukum dan Legal Culture}

Lapangan hukum yang dapat dimasuki oleh hukum Islam sebagai salah satu bahan baku hukum nasional, antara lain materi hukum sampai dengan etikanya, baik etika materi hukum, etika penegak hukum, maupun etika kelembagaan itu sendiri. Pembicaraan tentang etika hukum selama pemerintahan Orde baru, tampaknya tidak pernah menjadi wacana yang serius, apalagi menjadi penekanan dalam pembinaan hukum nasional. Barangkali karena kenyataan seperti inilah, hukum Indonesia sangat jauh dari idealitas yang seharusnya. Bukan saja tidak terjadi penegakan hukum, seperti yang disaksikan selama ini, tetapi dalam beberapa hal esensi hukum itu sendiri kurang mencerminkan nilai-nilai etika dan lebih mengedepankan pada formalisme hukum. ${ }^{\text {t9 }}$

Hukum dan keadilan tidak dapat dipisahkan, sehingga penerapan hukum tidak harus selalu bersifat formalitas lahiriah tanpa menampung keadilan yang sebenarnya. Dengan demikian, etika sangat dibutuhkan. Di samping itu, tanggung jawab hakim untuk menghasilkan putusan pengadilan yang benar-benar mewujudkan rasa keadilan itu akan erat kaitannya dengan hukum Islam, sebagai hukum yang bukan saja mempunyai konsekuensi dan tanggung jawab secara administratif di dunia namun juga mempunyai konsekuensi pahala dan dosa di akhirat kelak. Berbicara mengenai etika, hukum tanpa etika sama artinya bukan hukum atau bahkan sama artinya dengan kezaliman. Lebih jauh lagi, karena etika tidak menjadi perhatian, para penegak hukum sama sekali jauh dari nilainilai etika itu. Seberapa besar atau banyak etika hukum dijadikan mata kuliah di perguruan tinggi, baik di fakultas hukum, fakultas syari'ah, atau di fakultas lain, seperti filsafat atau bahkan lainnya, merupakan tanda sekaligus bukti seberapa serius etika hukum diperhatikan. Padahal di negaranegara Barat yang biasanya disebut sebagai negara sekular, nilai-nilai etika menjadi diskursus sehari-hari, termasuk etika hukum. Buku-buku mengenai etika hukum, di samping etika penegaknya, sangat banyak. Keadaan seperti inilah yang terjadi di Indonesia selama puluhan tahun, yang kemudian menghasilkan krisis hukum dalam konteks kolusi, korupsi dan nepotisme yang sangat populer itu. Jadi kebobrokan hukum merupakan salah satu sebab kehancuran bangsa Indonesia keseluruhan. ${ }^{19}$

Selain etika hukum, ada pula beberapa topik lain yang berkaitan dengan hukum, yang selama ini seolah lepas dari kajian serius ketika membahas hukum nasional, seperti budaya hukum (legal culture). Ketika membahas budaya hukum ini juga tidak dapat lepas dari hukum Islam. Hal ini merupakan topik kajian hukum kaitannya dengan hukum Islam yang selama ini belum tersentuh. ${ }^{20}$

Untuk pengembangan budaya hukum Islam di Indonesia kaum muslimin dihadapkan pada kemungkinankemungkinan, yaitu hukum positif Islam yang terbatas pada mempermasalahkan hukum yang berlaku bagi kaum muslimin,
${ }^{17}$ Ibid. 166-167.
18 lbid.
$19 \mathrm{lbid}$. hlm.167-168.
${ }^{20} \mathrm{lbid}$. hlm. 168. 
dan nilai-nilai hukum Islam, yang akan diberlakukan bagi seluruh warga negara, bahkan mungkin seluruh penduduk (termasuk yang bukan warga negara). Kedua alternatif tersebut akan mempengaruhi pembentukan hukum nasional pada masa yang akan datang. ${ }^{21}$

Alternatif pertama dapat dilihat pada masa sekarang sebagai kelanjutan politik hukum pada masa kolonial, baik melalui Aturan Peralihan Pasal II UUD 1945 maupun yang kemudian dituangkan ke dalam peraturan perundang-undangan baru. Ciri khas orientasi ini ialah masih diakuinya pembedaan hukum dalam hukum Barat, hukum Islam, dan hukum adat. Bidang yang terutama dijangkau adalah hukum perdata. Lembaga yang digunakan ialah pengadilan agama. Yang dimaksud dengan "hukum positif Islam" adalah hukum materill atau hukum substansi Peradilan Agama, yang berlaku di Pengadilan Agama Islam.22 Dapat dikatakan bahwa hukum positif Islam yang dicapai pada masa kini dan dikembangkan pada masa mendatang ialah segala hal tentang hukum yang akan dicapai dengan Undang-undang Peradilan Agama dengan Pengadilan Agama.

Alternatif kedua ialah hukum positif Islam yang bersumber dari nilai-nilai agama Islam. Kaum muslimin merumuskan asas-asas hukum Islam, kemudian menuangkannya sebanyak mungkin ke dalam hukum nasional. Dengan cara demikian pembudayaan hukum Islam tidak saja terjadi di bidang hukum perdata, khususnya hukum keluarga, tetapi juga di bidang lain, seperti hukum tata negara, dan hukum administrasi negara. Dengan orientasi ini, hukum Islam akan benar-benar menjadi sumber hukum nasional di samping Pancasila, tanpa menimbulkan anggapan bahwa hukum Islam adalah kuno. ${ }^{23}$
Model alternatif kedua di atas telah dilakukan oleh para penyusun Undang-undang Dasar 1945. Beberapa rumusan tersebut, seperti rumusan tentang ide bernegara bangsa Indonesia, yang dapat disarikan dari alinea II dan III Pembukaan UUD 1945, yang intinya ialah keadaan kehidupan berkelompok bangsa Indonesia, yang atas berkat rahmat Allah Yang Maha Kuasa; didorong oleh keinginan luhur bangsa; untuk berkehidupan kebangsaan yang bebas; dalam arti merdeka, berdaulat, adil, dan makmur. ${ }^{24}$

Rumusan ini jelas menunjukkan adanya nilai-nilai Islam jika umat Islam ingat bahwa yang menjiwainya adalah Piagam Jakarta. Rumusan ini tidak bersifat sekuler sebagaimana rumusan Rousseau (liberal) tentang negara yang beranggapan bahwa negara adalah hasil perjanjian individu-individu yang bebas. Jadi, rumusan Indonesia lebih integral. Demikian juga rumusan tentang kedudukan warga negara dalam hukum dan pemerintahan, sebagaimana dirumuskan di dalam pasal 27 ayat 1 (bahwa para warga negara sama kedudukannya di dalam hukum dan pemerintahan dan wajib menjunjung hukum dan pemerintahan tanpa kecuali). Hal ini berbeda dengan rumusan dalam sistem liberal, yang hanya menekankan equality before the law dalam hal rule of law-nya. Bangsa

${ }^{21}$ Padmo Wahjono, "Budaya Hukum Islam dalam Perspektif Pembentukan Hukum di Masa Datang", dalam Amrullah Ahmad dkk(Ed.)., Dimensi Hukum Islam dalam Sistem Hukum Nasional: Mengenang 65 Th Prof. Dr. H. Busthanul Arifin ( Jakarta: Gema Insani Press, 1996), hlm. 167.

22 Ibid. hlm. 167.

23 Ibid.

24 lbid. hlm. 172-173. 
Indonesia juga menegaskan kewajiban untuk mematuhinya dan menjamin kesamaan kedudukan di dalam pemerintahan. Hal ini adalah nilai-nilai Islam.

Demikian pula halnya dengan rumusan pasal 29 UUD 1945, yang menegaskan bahwa negara menjamin kemerdekaan tiap-tiap penduduk untuk memeluk agamanya masing-masing dan untuk beribadat menurut agamanya dan kepercayaannya itu. Melihat sejarah terjadinya, pada rumusan pasal ini jelas tampak pengaruh nilai-nilai Islam. Sebagai contoh, selanjutnya dapat dikemukakan rumusan pasal 34 UUD 1945: Fakir miskin dan anak yang terlantar dipelihara oleh negara. Rumusan ini juga tidak ada di dalam konstitusi-konstitusi liberal. Alternatif ini, lebih ideal karena menarik nilai-nilai (values) dari suatu pengaturan (hukum positif) masa lampau untuk mendapatkan asas-asas yang kemudian dirumuskan sebagai pengaturan (induktif) bagi semua warga negara, atau ditarik langsung nilai-nilai kehidupan dari Al-Qur'an, kemudian dijabarkan dalam asas dan pengaturan bagi semua warga negara (deduktif). ${ }^{25}$

Cara-cara inilah, yang dilakukan oleh bangsa-bangsa Islam pada masa lampau sehingga hukum positifnya betul-betul sesuai dengan situasi, kondisi, serta aspirasi rakyat, daripada sekadar mengambil alih hukum positif dari kurun waktu sebelumnya. Dengan demikian dapat dihindarkan dua kecenderungan yang sering terjadi, yaitu:umat Islam mempermasalahkan hukum Islam secara sekuler, dalam arti sekadar mengesahkan dan tidak perlu ikut campur di dalam hal materinya. Cara ini tampak pada politik hukum zaman kolonial; kecenderungan kedua ialah memandang hukum Islam sebagaimana layaknya di negara agama, yang di negara tersebut pendapat para ulama lebih diutamakan daripada aspirasi rakyat, padahal masalahnya berkenaan dengan hukum yang "ditangani" manusia awam, bukan Nabi. ${ }^{26}$

Mengingat negara Republik Indonesia bukan negara agama dan juga bukan negara sekuler, alternatif kedua ini adalah cara yang tepat. Namun demikian, terbentuknya suatu hukum tertulis oleh lembaga legislatif sangat dipengaruhi oleh ada tidaknya political will, yang akan membentuk politik hukum perundang-undangan. ${ }^{27}$

Praktik ketatanegaraan Indonesia menunjukkan bahwa belum dapat dihindarinya ataupun diatasinya keadaan transisi dari masa kolonial ke masa merdeka. Dalam keadaan demikian, Aturan Peralihan Pasal II UUD 1945 memainkan peran yang dominan; hukum dipakai sekadar untuk mengukuhkan suatu keadaan yang telah ada dan dianggap baik. Di sini jelas yang diutamakan adalah kepastian dan ketertiban, bukan suatu kemungkinan mengikuti perkembangan masyarakat. Dalam suasana seperti itu, generasi berikut sering merasa terhambat dalam menyalurkan aspirasinya; dan hukum adalah hasil rekayasa kekuatan-kekuatan sosial dalam masyarakat, atau hukum dipakai untuk merekayasa masyarakat (law as a tool of social engineering) ${ }^{28}$

Hukum sebagai rekayasa, hukum benar-benar dipakai untuk merealisasikan kepentingan masyarakat dan bangsa tanpa memperhatikan kepentingan golongan ekonomi, status sosial, asal-usul, agama, suku bangsa, dan sebagainya. Contohnya ialah rekayasa tentang Norma Keluarga

\footnotetext{
25 /bid. hlm. 173.

26 Ibid.

27 Ibid.

${ }^{28}$ Ibid. him. 174.
} 
Kecil Bahagia dan Sejahtera (NKKBS), rekayasa tentang pekerjaan yang layak dari segi kemanusiaan (tukang becak dan pedagang asongan), dan rekayasa tentang kawasan industri berdasarkan analisa dampak lingkungan (ANDAL). Dengan demikian, dalam memasalahkan hukum Islam di masa mendatang, tidak tepat apabila sekadar mengikuti political will berdasarkan ragam politik hukum sebagaimana disebutkan di atas, melainkan bahwa hukum Islam dipakai untuk merekayasa masyarakat sebagai realisasi aspirasi rakyat atau kepentingan masyarakat. ${ }^{29}$

Apabila pembudayaan hukum Islam dikaitkan dengan pembentukan hukum di masa akan datang serta ragam politik hukum yang mendasarinya berkaitan dengan "struktur" suatu sistem hukum, memahami teori tentang peringkatan hukum menjadi relevan. Teori peringkatan hukum beranggapan bahwa berlakunya suatu hukum harus dapat dikembalikan kepada hukum yang lebih tinggi kedudukannya. Dengan demikian, akan terdapat tingkatan cita-cita hukum yang merupakan norma yang abstrak; norma antara yang dipakai sebagai perantara untuk mencapai cita-cita hukum; dan norma konkret (concrete norm) yang dinikmati orang sebagai hasil penerapan norma antara atau penegakannya di pengadilan. ${ }^{30}$

Apabila teori pertingkatan hukum ini diterapkan pada UUD 1945, sebagaimana dijelaskan oleh para perumus UUD 1945 pada bagian penjelasan, diperoleh gambaran bahwa pokok-pokok pikiran yang terkandung di dalam Pembukaan, mewujudkan cita-cita hukum yang menguasai hukum dasar negara, baik hukum yang tidak tertulis bagi bangsa Indonesia (Norma Hukum Abstrak) merupakan cita-cita hukum bangsa Indonesia (Norma Hukum Abstrak).
Undang-Undang Dasar menciptakan pokok-pokok pikiran dalam pasal-pasalnya dan Aturan-aturan menyelenggarakan aturan pokok diserahkan kepada undang-undang (Norma Hukum Antara). Jadi, norma hukum antara adalah peraturan perundang-undangan diawali oleh pasal-pasal UUD 1945. Pedomannya ada di dalam penjelasan pasal 28 , dengan hukum (konkret) harus berdimensi tiga, yaitu demokratis, berperikemanusiaan, dan keadilan sosial. ${ }^{31}$

Apabila teori pertingkatan hukum ini diterapkan pada permasalahan hukum Islam sebagai sumber hukum nasional pada masa yang akan datang, gambaran pertingkatan hukumnya adalah nilai-nilai di dalam Kitab Suci Al-Qur'an (universal dan abadi dan tidak boleh diubah manusia) merupakan norma abstrak dan cita-cita hukum. Sedangkan asas-asas (principles) serta pengaturan, hasil kreasi manusia sesuai dengan situasi, kondisi, budaya, dan kurun waktu, yang muncul sebagai peraturan negara, pendapat ulama, pakar! ilmuwan, atau kebiasaan, menjadi norma antara. Semua (hasil) penerapan dan pelayanan hukum kreasi manusia bukan nabi, serta hasil penegakan hukum di pengadilan (hukum positif, living-law) merupakan norma konkret. ${ }^{32}$ Secara ringkas, dapat dirumuskan, yaitu: nilai-nilai Islam; asas-asas dan penuangannya ke dalam hukum nasional; dan penerapan serta penegakannya di dalam hukum positif. ${ }^{33}$

Berpangkal tolak dari kerangka pernikiran bahwa hukum positif Isiam pada masa mendatang adalah hukum yang
29 Ibid.
${ }^{30} \mathrm{lbid}$. hlm. 175.
31 Ibid.
32 Ibid. hlm. 175-176.
33 Ibid. hlm. 176. 
bersumber dari nilai-nilai agama Islam dan dihubungkan pula dengan teori peringkatan hukum, hukum Islam dapat diterjemahkan sebagai kepentingan umum rakyat dalam segala aspeknya, mencakup bidang yang begitu luas, seperti ekonomi, hukum, politik dan sebagainya (mu'amalah). Nilai-nilai Islam (norma hukum) yang abstrak atau cita-cita hukum. Oleh karena itu, dibutuhkan formulasi asas-asas, peraturan (perundang-undangan) atau bentuk legislasi lainnya sebagai norma antara yang merupakan kreativitas ijtihad yang disesuaikan dengan situasi, kondisi, budaya dan kurun waktu. Semua hasil penerapan dan penegakan norma antara tersebut menjadi hukum positif yang merupakan norma konkret (living law) masyarakat.

Apabila formulasi dan aplikasi suatu peraturan perundang-undangan dalam berbagai bidang seperti ekonomi, politik, hukum (norma antara) mampu mewujudkan kepentingan umum rakyat banyak dalam arti sebenarnya dan dapat pula merekayasa tercapainya cita-cita kehidupan rakyat banyak, berarti aturan-aturan tersebut masih mungkin dan dapat dipertahankan. Akan tetapi, jika sebaliknya, justru formulasi dan aplikasi berbagai peraturan perundangundangan dalam berbagai lapangan kehidupan rakyat banyak itu tidak mampu lagi menampung aspirasi kerakyatan dikarenakan adanya faktor perubahan situasi dan kondisi, dibutuhkan aturan-aturan yang baru sama sekali. Dengan demikian, kepentingan umum rakyat merupakan cita-cita atau tujuan yyang hendak diwujudkan, sedangkan peraturan-peraturan undang-undang merupakan sarana untuk mewujudkan cita-cita kerakyatan. Oleh karena itu efektivitas suatu sarana dapat dipantau oleh masyarakat.

Dalam kaitan ini, yang terpenting adalah bagaimana nilai-nilai Islam dapat terpatri dalam kehidupan bernegara, masyarakat, bangsa, keluarga dan individu, kemudian menegakkan keadilan sosial dan menciptakan suatu masyarakat egalitarian, jauh dari eksploitasi manusia atas manusia lain maupun eksploitasi golongan atas golongan lain. Dengan kata lain, hukum Islam tidak dalam norma, melainkan dalam substansinya. ${ }^{34}$

\section{Strategi dan Pendekatan Transfi- gurasi Hukum Islam}

Jika diamati masyarakat Islam Indonesia, khususnya para tokoh muslim yang terlibat dalam pembahasan mengenai pemberlakuan hukum Islam di Indonesia, setidaknya ada dua kelompok, yaitu kelompok yang menekankan pada pendekatan normatif (formalisme) dan kelompok yang menekankan pada pendekatan kultural (budaya). Pendekatan ini sebagai perwujudan kehidupan politik dari masing-masing kelompok, atau justru sebaliknya, yakni bahwa cermin politik mereka sebagai wujud keyakinan terhadap jenis pendekatan tersebut. Hal ini juga sekaligus sebagai jawaban dari persoalan bagaimana penerapan hukum Islam, ketika disepakati bahwa hukum Islam merupakan salah satu dari tiga bahan baku dalam pembinaan hukum nasional. Penjelasan berikut ini akan diungkapkan baik pendekatan formal maupun kultural. ${ }^{35}$

Pertama, pendekatan formal (normatif). Menurut pendapat ini, hukum Islam harus diterapkan kepada mereka yang sudah mengucapkan dua kalimah syahadah atau

${ }^{34}$ Yusdani, Peranan Kepentingan Umum dalam Reaktualisasi Hukum: Kajian Konsep Hukum Islam Najamuddin At-Tufi (Yogyakarta: UII-Press, 2000), hlm.137.

${ }^{35}$ A. Qodri Azizy, Eklektisisme...hlm.194. 
sudah masuk Islam. Istilah " transfigurasi hukum Islam" tidak akan populer, kecuali berarti bahwa mereka yang beragama Islam Islam dengan harus menjalankan atau dipaksakan untuk menerima hukum Islam dalam kehidupan sehari-hari. Oleh karena itu, proses kehidupan politik, termasuk partai politik, adalah dalam rangka atau sebagai alat untuk menerapkan hukum Islam secara normatif dan formal ini. Konsekuensinya, pelaksanaan Piagam Jakarta menjadi persoalan besar dan serius yang harus selalu diperjuangkan, oleh karena merupakan satu-satunya cara untuk penerapan hukum Islam secara formal kalau perlu dipaksakan - di negara Indonesia. Jika ditarik ke atas lagi dari sisi ekstrimitas, pendekatan ini menjadi skriptualis dan tekstualis yang biasanya kurang mempertimbangkan kontekstual dan lingkungan sosiologis. Pada dasarnya pendekatan normatif tidak terlalu jelek jika akan dapat diposisikan sebagai pengontrol. Namun jika berlebihan akan sampai pada skriptualis dan pemaksaan tersebut. Sampai batas ini, upaya transfigurasi tidak merupakan jawaban karena cenderung pada pemaksaan secara formal ideologis. Dan jika pendekatan ini yang diterapkan, persoalan yang muncul, adalah hukum Islam yang mana yang dimaksud? Pertanyaan ini sangat serius, terutama sekali ketika ditemukan kenyataan terjadinya perbedaan pendapat tentang hukum Islam itu sendiri. Persoalan seperti inilah yang sering terjadi sebagai ekses upaya islamisasi di beberapa negara di Timur Tengah yang kemudian hampir tidak pernah selesai. Tampaknya pertanyaan hukum Islam yang mana ini yang akan selalu muncul ke permukaan, seandainya perjuangan menerapkan Piagam Jakarta itu berhasil. Persoalan tersebut bukan masalah kecil, namun dapat menjadi masalah serius, terutama sekali ketika tidak dapat disatukan dalam menerima definisi tentang hukum Islam itu sendiri.

Kedua, Pendekatan kultural. Menurut pendapat ini, yang terpenting bukan formalisme penerapan hukum Islam atau dengan pendekatan normatif ideologis. Namun penyerapan nilai-nilai hukum Islam ke dalam masyarakat itulah yang lebih penting. Barangkali dapat dijadikan contoh pendekatan yang kedua ini adalah ungkapan K. H. M. A. Sahal Mahfudh. Menurutrnya, " terciptanya hukum yang ideal dalam masyarakat madani dengan demikian harus dimulai juga dengan menyerap nilai-nilai hukum universal tersebut di atas dalam kerangka kemasyarakatan yang proporsional". Nilai-nilai hukum universal yang dimaksudkan itu meliputi: keadilan, kejujuran, kebebasan, persamaan di muka hukum, perlindungan hukum terhadap masyarakat tak seagama, dan menjunjung tinggi supremasi hukum Allah. Maksudnya adalah bahwa 'nilai tersebut harus diupayakan tertanam dan terimplementasikan dalam segala unsur masyarakat madani, mulai dari sistim kelembagaan dan unsur masyarakat pendukungnya". Dengan istilah penyerapan nilai, berarti bahwa prosesnya itu bersifat kultural, bukan pemaksaan secara normatif. Dengan pendekatan secara kultural seperti ini, K.H. Sahal yakin "akan memperkecil kendala yang ada pada tahap implementasi". Oleh karena itu, menurut K. H. Sahal "labelisasi yang sering menimbulkan sikap antipati dan kecurigaan dari kalangan masyarakat juga hendaknya diminimalkan". Setelah menguraikan cukup panjang dalam artikel berjudul "Peranan Hukum Islam dalam Menciptakan Masyarakat Madani Indonesia", K.H.M.A. Sahal Mahfudh lebih jauh lagi mengatakan sebagai berikut:

Menciptakan masyarakat madani dalam konteks ke-Indonesiaan dari kaca 
mata hukum Islam, dengan demikian tidak "dengan" atau "tanpa" hukum Isiam, namun lebih kepada mempertimbangkan dan menyerap nilai-nilai moral positif yang terkandung dalam hukum Islam itu sendiri. Menerapkan hukum Islam dalam arti formalisasi hukum Islam terkadang belum merupakan solusi terbaik bagi proses formulasi hukum yang ideal bagi sebuah masyarakat madani. Demikian pula eliminasi hukum-hukum yang ada dalam masyarakat, khususnya hukum Islam dalam proses tersebut juga bukan merupakan langkah yang bijaksana, karena bagaimana keberadaannya, baik sebagai sebuah nilai maupun sebagai sebuah peraturan yang yang berlaku tetap mendapatkan legitimasi yang kuat dalam masyarakat Indonesia. Namun meskipun demikian, ruang gerak bagi proses berkembangnya hukum-hukum yang ada di Indonesia, terutama hukum Islam, harus tetap dibiarkan leluasa. Hal demikian ini untuk merangsang agar hukumhukum tersebut bisa lebih berkembang dinamis yang pada gilirannya juga akan memberikan sumbangan yang dinamis pula bagí perkembangan hukum Indonesia secara keseluruhan. ${ }^{36}$

Dari uraian tersebut jelaslah posisi dan upaya serta pendekatan yang dilakukan oleh kelompok kedua atau kelompok yang menggunakan pendekatan kultural ini. Sudah barang tentu bagi kelompok kedua ini ungkapan dan sekaligus pendekatan pertama di atas dapat dikatakan berlebihan. Termasuk terhadap hukum waris yang dianggap lebih menekankan pada saling merelakan di antara keluarga itu. Artinya, pembagaian harta waris atas dasar rela sama rela diperkenankan. Bahkan, seandainya salah satu pihak tidak menerima bagiannya atas dasar kerelaannya juga tidak dianggap bersalah. Justru yang sering terjadi adalah dengan menggunakan konsep

hibah. Barangkali praktek hibah dan saling merelakan tersebut yang pernah menjadikan Hurgronje salah paham, sebagai pelaksanaan hukum seperti kalau diputuskan di Pengadilan. Dalam peradilan Islam, ada perbedaan yang mendasar antara pembagian waris atas dasar rela sama rela atau hibah dengan putusan pengadilan yang berangkat dari persengketaan. Reia sama rela dalam masalah yang berhubungan antar sesama manusia (perdata) berarti mendasarkan pada perasaan hati . Ketika hukum seperti itu dapat diterapkan, hukum yang kaku dan formal itu tidak harus dibawa ke pengadilan. Sedangkan hukum yang karena persengketaaan harus diputuskan sesuai dengan ketentuan hukum waris, ketika harus diselesaikan di pengadilan. Di samping itu, sudah menjadi kebiasaan umat Islam dalam perkara warisan bahwa mereka akan pergi ke pengadilan, ketika terjadi persengketaan di antara mereka sendiri. Sedangkan kalau tidak terjadi persengketaan, biasanya pembagian harta waris dilakukan atas dasar saling merelakan, yang salah satu bentuknya adalah hibah. ${ }^{37}$

Sedangkan kajian hukum Islam di Indonesia yang akan datang tidak menggunakan pendekatan normatif dan formalisme, namun juga tidak semata-mata dengan menggunakan pendekatan kultural secara longgar dan dalam pengertian yang pasif. Proses kultural memang suatu modal yang sangat berharga. Bahkan di dalam kajian hukum pada umumnya, budaya

${ }^{36}$ K.H. M.A. Sahal Mahfudh. 2001. “Peran Hukum Islam dalam Menciptakan Masyarakat Madani Indonesia", Makalah Disampaikan dalam Diskusi di Pascasarjana IAIN Walisongo Semarang pada tanggal 27 September 2001.

${ }^{37}$ A. Qodri Azizy, Eklektisisme....him.197198. 
hukum itu salah satu topik pembahasan yang serius secara akademik. Dan GBHN 1999 juga terjadi budaya hukum secara umum sebagai salah satu program selama lima tahun ke depan ini. Transfigurasi hukum Islam dalam pembangunan hukum nasional dapat terjadi baik dengan pendekatan normatif maupun dengan pendekatan kultural, setelah mendapat justifikasi argumentasi keilmuan atau akademik dalam kajian hukum di Indonesia secara terbuka. Sudah barang tentu kesemuanya itu dalam koridor demokratisasi dan pemeliharaan hak asasi manusia yang sangat mementingkan pada hak-hak individu , tanpa mengorbankan hak publik. Kesemuanya itu dalam rangka realisasi GBHN 1999, yang lebih tegas menjelaskan adanya sumber hukum nasional, salah satu sumbernya adalah hukum Islam, tanpa harus melibatkan Piagam Jakarta. ${ }^{38}$

\section{Penutup}

Dalam konteks transfigurasi hukum Islam dalam sistem hukum Indonesia, perlu bagi para hukum Islam Indonesia memahami posisi aliran hukum nasional dalam kerangka aliran hukum di dalam ilmu hukum pada umumnya. Dengan pemahaman terhadap aliran hukum nasional tersebut, akan nampak secara jelas tanggung jawab hakim dalam mengembangkan hukum dan seberapa jauh transfigurasi itu dapat dilaksanakan tanpa dengan pemaksaan. $\mathrm{Di}$ samping itu seberapa jauh pula transfigurasi itu dapat dilakukan melalui perundangundangan yang ada di Indonesia.

Strategi Transfigurasi hukum Islam di Indonesia tentu berbeda dengan konsep teori resepsi pada masa lalu, karena resepsi tidak mengenal usaha yang strategis dan demokratis, sebab teori resepsi itu sendiri merupakan bagian dan perwujudan indoktrinasi yang anti Islam. ${ }^{39}$ Proses transfigurasi hukum Islam dilakukan tetap melalui kerangka keilmuan dalam disiplin limu Hukum jika ditinjau dari aspek akademik, dan tetap dalam koridor demokratisasi jika ditinjau dari segi sistem politik.Kerangka dan tinjauan keilmuan dan demokratisasi harus dilakukan dalam era reformasi dan pada masa yang akan datang. Untuk mendukung upaya di atas, usaha intelektual atau penelitian merupakan suatu aktivitas yang harus dilakukan dalam dunia modern yang menjunjung tinggi kebebasan akademik dan proses demokratisasi. ${ }^{40}$ Transfigurasi hukum Islam dalam pembangunan hukum nasional dapat terjadi baik dengan pendekatan normatif maupun dengan pendekatan kultural, setelah mendapat justifikasi argumentasi keilmuan atau akademik dalam kajian hukum di Indonesia secara terbuka.

\section{Daftar Pustaka}

Anderson, J.N.D. 1976. Law Reform in the Muslim World. London: University of London Press.

1975. Islamic Law in the Modern World. New York: New York University Press.

Azizy, A. Qodri,2002. Eklektisisme Hukum NasionalKompetisi Antar Hukum Islam dan Hukum Umum .Yogyakarta:Gama Media.

Coulson, N.J. ,1969. Conflicts and Tensions in Islamic Jurisprudence. Chi- 
Topik: Transfigurasi Hukum Islam dalam Sistem Hukum Nasional , Yusdani

cago dan London: the University of Chicago Press.

1994. A History of Islamic Law. Edinburgh: Edinburgh University Press.

\section{GBHN 1999}

Kansil, C.S.T. dan Christine S.T. Kansil, 2000. Pengantar IImu Hukum dan Tata Hukum Indonesia. Jakarta: Balai Pustaka

Mahfudh, K.H. M.A. Sahal. 2001. "Peran Hukum Islam dalam Menciptakan Masyarakat Madani Indonesia", Makalah Disampaikan dalam Diskusi di Pascasarjana IAIN Walisongo Semarang pada tanggal 27 September 2001 .

Mu'allim, Amir dan Yusdani. 1999. Konfigurasi Pemikiran Hukum Islam. Yogyakarta: UII Press.

Murphy, Jeffrie dan Jules.1984. The Philosophy of Law. New Jersey: Rowman \& Allanheld

Na'im, Abdullahi Ahmed. 1990. Toward an Islamic Reformation: Civil Liberties, Human Rights and International Law. New York:Syracus University Press.

(Editor). 2002. Islamic Family Law in a Changing World: A Global Resource Book. London - New York: Zed Books Ltd.

Radhie, Teuku Muhammad. 1983. Peranan Hukum Islam Dalam Pembinaan Hukum Nasional. Yogyakarta: TTP
Rahardjo, Satjipto. 1980. Hukum dan Masyarakat. Bandung: Angkasa

Rahman, Fazlur.1970. Toward Reformulating the Methodology of Islamic Law: Shaikh Yamani on Public Interest in Islamic Law. International Law and Politic.

1980. Major Themes of the Quran. Chicago: Bibliotheca Islamic.

Schacht, Joseph. 1971. An Introduction to Islamic Law. London: Oxford at the Clarendon Press.

1960. "Problems of Modern Islamic Legisiation". Dalam Studica Islamica, vol. 12, hlm. 120.

Thalib, Sajuti.1982. Receptio A Contrario (Hubungan HukumAdat dengan Hukum (slam). Jakarta: Bina Aksara.

Undang-Undang No. 14 tahun 1970

Undang-Undang No. 35 tahun 1999

Wahjono, Padmo.1996. "Budaya Hukum Islam dalam Perspektif Hukum di Indonesia Masa Datang, dalam Amrullah ahmad dkk (Ed.) Dimensi Hukum Islam dalam Sistem Hukum Nasional Mengenang 65 TH Prof. Dr. H. Busthanul Arifin SH. Jakarta: Gema Insani Press.

Yusdani. 2000. Peranan Kepentingan Umum Dalam Reaktualisasi Hukum: Kajian Hukum Islam Najamuddin AtTufi. Yogyakarta: UII Press. 